\title{
Allelopathic Potential of the Aqueous Extract of Raphanus sativus L. on the Germination of Beans and Corn Seeds
}

\author{
Marli de Moraes Gomes' ${ }^{1}$, Douglas Junior Bertoncelli ${ }^{1}$, Guilherme Augusto Cito Alves ${ }^{1}$, \\ Gustavo Henrique Freiria1, Felipe Favoretto Furlan', Guilherme Renato Gomes', \\ Vitor Rampazzo Favoretto르, Helio Fernandes Ibanhes Neto'1, Mônica Satie Omura', \\ Jose Roberto Pinto de Souza ${ }^{1}$
}

${ }^{1}$ Graduate Program in Agronomy, State University of Londrina, Londrina, PR, Brazil

${ }^{2}$ Agronomy, State University of Londrina, Londrina, PR, Brazil

Email:dj_bertoncelli@hotmail.com

How to cite this paper: de Moraes Gomes, M., Bertoncelli Jr., D., Alves, G.A.C., Freiria, G.H., Furlan, F.F., Gomes, G.R., Favoretto, V.R., Neto, H.F.I., Omura, M.S. and de Souza, J.R.P. (2017) Allelopathic Potential of the Aqueous Extract of Raphanus sativus L. on the Germination of Beans and Corn Seeds. Open Access Library Journal, 4: e3590.

https://doi.org/10.4236/oalib.1103590

Received: April 10, 2017

Accepted: May 13, 2017

Published: May 16, 2017

Copyright $\odot 2017$ by authors and Open Access Library Inc.

This work is licensed under the Creative Commons Attribution International License (CC BY 4.0).

http://creativecommons.org/licenses/by/4.0/

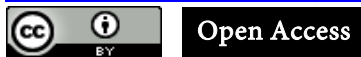

\begin{abstract}
The plants synthetize a big quantity of chemically diverse compounds, which discharged into the environment influence in a decisive manner in the species dynamics that form the agroecosystems, phenomenon denominated allelopathy. The study had the aim of the evaluation of allelopathic effects of turnip aqueous extract under beans and corn seeds. The experimental design was completely randomized with five treatments (concentrations of $0 \%, 25 \%, 50 \%$, $75 \%$ and $100 \%$ of raw extract) and four repetitions. The gross extract was prepared through the mixture of $50 \mathrm{~g}$ of turnips aerial part fresh mass in 450 $\mathrm{mL}$ of cold distilled water and then blended in a blender. The mixture was kept in rest in absence of light for 24 hours at $25^{\circ} \mathrm{C}$ for posterior filtration and dilution of concentrations. They were evaluated the percentage of germination and the germination velocity index in Germitest paper rolls dampened with the extract or distilled water, according to the treatments and each roll was distributed 50 seeds, kept in germination chamber at $25^{\circ} \mathrm{C} \pm 3^{\circ} \mathrm{C}$ and 12 hours of photoperiod. At the end of seven (corn) and nine (beans) days, the root length (RL) and the aerial part (APL) were evaluated, and after drying in a hothouse $\left(50^{\circ} \mathrm{C}\right)$, the dry mass of root system (DMR) and aerial part (DMAP) was determined, by the measure of 20 plantlets of each treatment. The results were submitted to an analysis of variance by $\mathrm{F}$ test and, when there was statistical significance, it was made the regression analysis test. For the realization of the statistical analysis, the ASSISTAT software was used. The turnip aqueous extract affected negatively the germination and initial development of bean and corn plantlets.
\end{abstract}




\section{Subject Areas}

Agricultural Science

\section{Keywords}

Allelopathic, Raphanus sativus L., Phaseolus vulgaris L., Zea mays L.

\section{Introduction}

Among the cover crops present in the direct seedling system, the turnip (Raphanus sativus L.), an annual brassicaceae used for green fertilization and crop rotation in the South, Southwest and Midwest regions of Brazil in the winter period, is highlighted by its low cost, fast growth and short cycle [1] [2].

The cultural remaining of the cover crops could present allelopathic effects that affect the germination and the development of the subsequent crop, by means of the chemical substances distributed through the decomposition of the plant material. It liberates directly in the soil a variety of compounds, capable of influencing the development of the plants and microorganisms that are found in it. The allelopathic effect can occur as much during the crop cycle as in the subsequent crops [3].

The allelochemicals could act directly on the metabolism of the target plant, affecting the cellular structure, hormonal regulation, membrane permeability, nutrients absorption, photosynthesis, protein synthesis, enzyme activity, among other changes [4]. Due to the fact that the metabolism is interlinked; the alteration of a unique mechanism could affect entire routes.

The interaction with the environment can amend positively or negatively the allelopathic effect of a determined compound, being this factor one of the main obstacles in the study of allelopathy, limiting then, the knowledge around the mechanism by which the allelopathic substances cause toxicity [5].

In the attempt of reducing the interference on the possible allelochemicals, compound is common in the allelopathy researching the utilization of vegetation extracts from the studding plant. In which the "extraction" is comprehended as the selective and complete removal of the substance of active fraction from the vegetable drug of interest, for that there are employed appropriate solvents, such as water and ethanol [6].

Allelopathic effects of some green fertilizers employed as dead cover (cover crops), have been reported as velvet bean (Mucuna aterrima) on bean (Phaseolus vulgaris L.) [7]; Pearl Millet (Pennisetum americanum) on soy bean (Glycine $\max$ L.) [8]; Tokura and Nóbrega [9] observed that the aqueous extract of turnip presented allelopathic effect in the germination and in the initial development of corn plantlets.

Moraes et al. [10] observed that the extract of (Raphanus sativus), as canola (Brassica napus) and arrow leaf clover (Trifolium vesiculosum), presented allelopathic effect on the germination and initial development of blackjack plantlets 


\section{(Bidenspilosa).}

In Brazil, big part of the studies with allelopathy are restricted to the occurred interference in growth and development of cultivated plants, mainly in management with crop rotation, being the allelopathic interferences related to the development of the most studied weed plants [9].

Inside the exposed, the aim of this study was to evaluate the turnip allelopathic potential on germination and initial development in plantlets of Phaseolus vulgaris L. and Zea mays L.

\section{Material \& Methods}

The experimente was conducted in the Universidade Estadual de Londrina (Londrina State University) - Parana State-Brazil, located in 2320'23.45" South latitude, $51^{\circ} 12^{\prime} 32.28^{\prime \prime}$ West longitude and average height of $532 \mathrm{~m}$. According to the Koppen classification the region is in Cfa climate, with hot summers and low frequency of frosting, and soil kind Red Nitossolo eutroferrico latossolico [11]. The experiment was conducted in the months of May to July (autumn period), Average temperature of $18^{\circ} \mathrm{C}$, rainfall during the experiment period of 435.2 $\mathrm{mm}$, average relative humidity of $75 \%$.

The turnip (Raphanus sativus L.) plants, cultivar CATI AL 1000 with germination percentage of $60 \%$, were cultivated as green fertilizers in the university's experimental area, seeded with $25 \mathrm{~cm}$ of spacing between lines and density of 30 seeds by linear meter.

The fresh mass of plants was collected in the morning period in flowering time (70 Days After Emergence-DAE) with the aid of a pruning shears, removing just the aerial part (stem, leafs and flowers), onward conveyed to the laboratory to the plant extract preparation.

For the acquisition of the raw extract by maceration in the concentration of $100 \%$ (weight/volume), there was used $50 \mathrm{~g}$ of turnip plants' aerial part fresh mass. This material was chopped and mixed to $450 \mathrm{~mL}$ of cold distilled water for 24 hours and later blended in a commercial blender. In sequence, the mixture was kept in rest in the absence of light for a period of 24 hours in average temperature of $25^{\circ} \mathrm{C}$. After this period, the filtering was made in filter paper, separating the solid part from the solution.

Onwards the gross extract was made the dilutions in distilled water to obtain the concentrations (v/v) of $25 \%, 50 \%, 75 \%$ and $100 \%$. The effects of the extracts were compared with the control (distilled water, considered $0 \%$ ).

As bio indicators were used commercial seeds of beans (ANF C9) and corn (30f53) for the application of the extract. The employed tests followed the Rules for Seeds Analysis [12]. The germination test was realized in Germitest paper rolls, which were dampened with the extract or distilled water, according to the treatments and in each roll, 50 seeds were put. The quantity of solution used was determined multiplying two times and a half the papers' weight. The rolls were kept in germination chamber (BOD) with average temperature of de $25^{\circ} \mathrm{C} \pm 3^{\circ} \mathrm{C}$ and photoperiod of 12 hours. 
The experimental design was completely randomized with five treatments (concentrations of $0 \%, 25 \%, 50 \%, 75 \%$ and $100 \%$ from raw extract) and eight repetitions.

Daily, during seven days for corn and nine for bean [12], were made counting of the germinated seeds number, to establish the germination velocity index (GVI), obtained through the formula described by Maguire [13], modified by Wardle et al. [14]: GV $=[\mathrm{N} 1 / 1+\mathrm{N} 2 / 2+\mathrm{N} 3 / 3+\cdots \mathrm{Nn} / \mathrm{N}]$. Where, N1, N2, N3 and $\mathrm{Nn}$ are the numbers of germinated seeds and 1, 2, 3 and $\mathrm{n}$ represent the number of days after seedling.

At the end of the period, were evaluated the germination, the root length (RL) and the aerial part (APL), and after drying in a hothouse $\left(50^{\circ} \mathrm{C}\right)$, was determined the dry mass of the root system (DMR) and from the aerial part (DMAP), by the measure of 20 plantlets of each experimental unit (repetition) of five treatments.

The obtained results were tabled and submitted to the analysis of variance by the F test, and when there was a statistical significance, there was made the regression analysis test. For the realizations of the statistical analysis, the ASSISTAT software was used.

\section{Results \& Discussion}

The application of Raphanus sativus L.'s extract affected negatively the germination of the seeds of bean and corn (Figure 1), where the increase of the concentration lead to the diminution of the germination percentage.

Araujo et al. [15], verified that the germination process of the bean seed was totally compromised, irrespective of the used Crotalaria juncea aqueous extract concentration. The authors justified this behavior suggesting that seeds' morphological aspects had eased the entry of allelopathic substances in its interior.

According to Souza Filho [16], the level of inhibition provided by determinates allelochemicals vary according to its concentration, being that in low concentrations could not be inhibitors for determined species or even present stimulant effect, on the other side when it is in high concentrations the substances could be completely inhibitory.
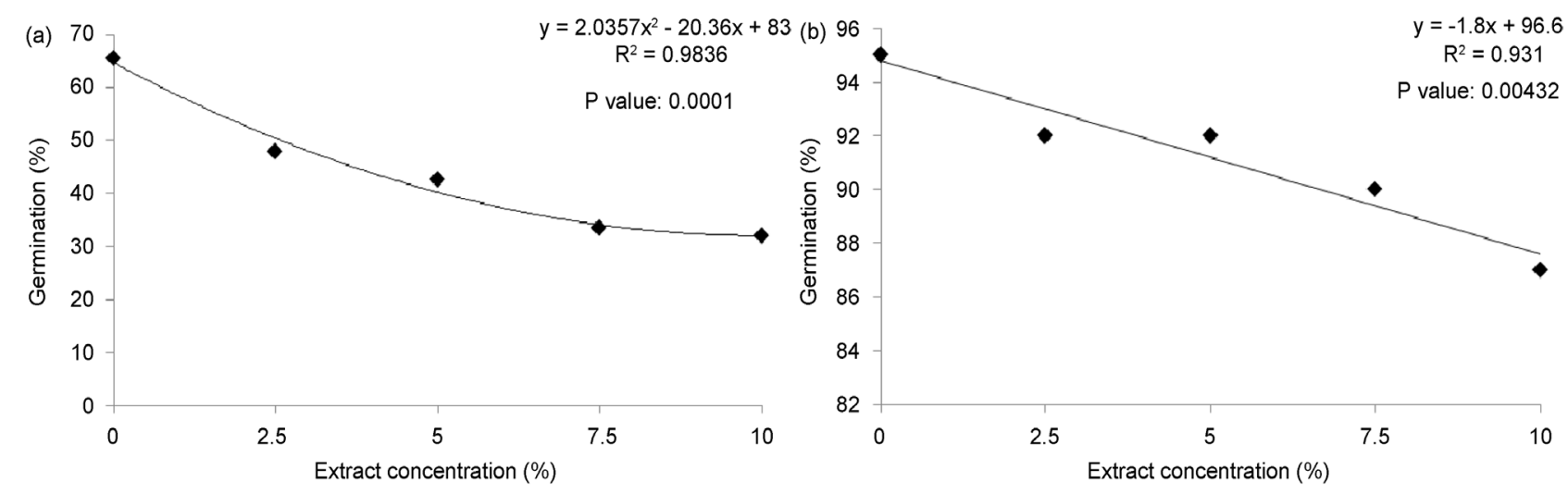

Figure 1. Germination (\%) of seeds of (a) - Phaseolus vulgaris L. and (b)-Zea mays L. in five concentrations of the turnip extract. UEL, Londrina, PR, 2015. 
The germination velocity index (VGI) reduced with the increase of the concentration of the plant extract for the seeds of bean and corn (Figure 2). A similar result was observed by Rickli et al. [17], where the application of the neem tree (Azarirachiaindica) aqueous extract on bean and soybeans seeds, reduced the GVI with the increase of the extract concentration. The authors complemented that this alteration in the germination of the seed is considered very problematic, because alter the uniformity of germination results in prejudices in harvest, due to the desuniformity of the plants final stand.

According to Santos et al., [18], substances consider inhibitory possess a stimulating effect under low concentrations; with the inhibitors seem to act on the enzyme activity and/or the physiological activity of the plant, stimulating the plant metabolism activity.

These alterations in the germination process of the seed are interlinked to the water flow to the interior of the cells, which can carry with themselves some allelopathic substances that hinder or delay the division or growth of the cells, resulting in a delay of germination [19].

The modification in the germination process in the presence of plant extracts normally is due to the presence of phenolic compounds that cause inhibition of the synthesis of gibberelic acid and or the activity of $\alpha$-amilase enzyme, what affects the seeds germination, by interfering in the hydrolytic enzymatic system and of mobilization of reserves [20].

The root length of plantlets of bean and corn showed reduction of the growth with the turnip's extract concentration elevation (Figure 3). A similar result was obtained with the neem tree (Azarirachiaindica) aqueous extract application on corn, soybean and bean seeds, where there was a reduction of the root length with the increase of the applied extract's concentration [17].

According to Ferrarese et al., [21], the phenolic compounds are powerful allelochemicals that induce the increase of the oxidative enzymes' activity, having as consequence the modification of the membrane permeability and the formation of lignin, reducing the root growth.

As well as the root length, the aerial part of the corn and beans plantlets also

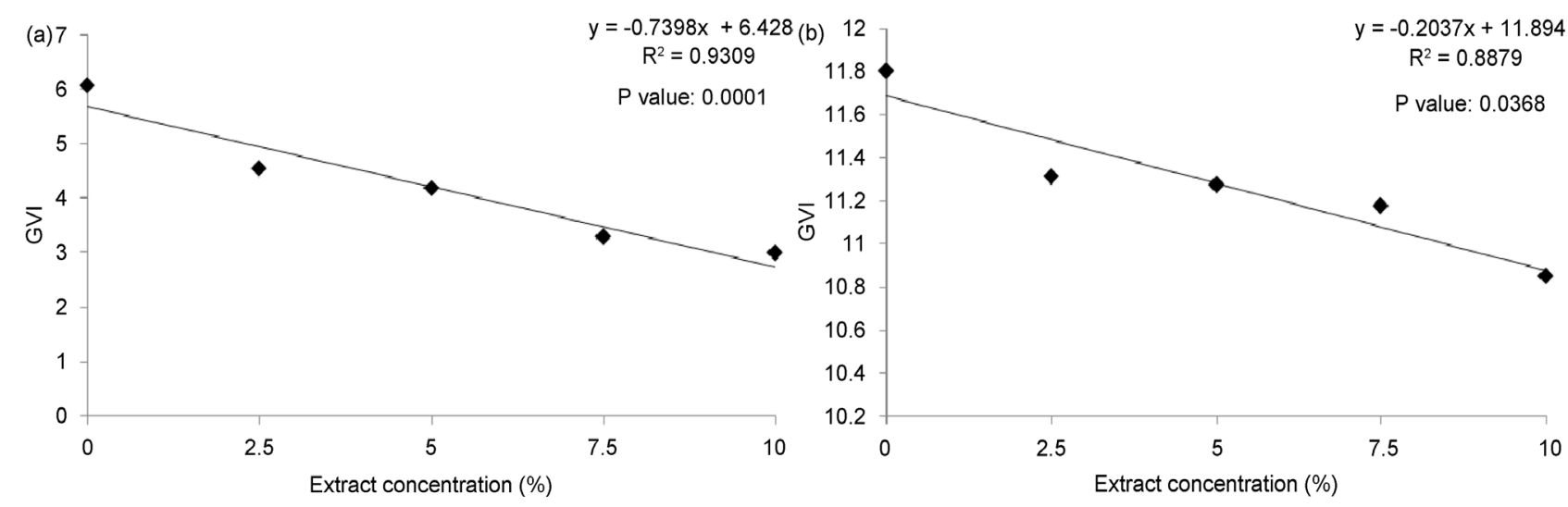

Figure 2. Germination velocity index (GVI) of seeds of (a) - Phaseolus vulgaris L. and (b) - Zea mays L. in different concentrations of turnip's extract. UEL, Londrina, PR, 2015. 
presented reduction in growth with the increase of the turnip extract concentrations applied to the seeds (Figure 4). Similar result was observed by Araujo et al. [15], where the increase of the concentration of the extract of Crotalaria juncea, caused reduction of the aerial parts length of beans plantlets.

In accordance with Sousa and Bortolon [22], the reduction of root growth decreases the absorption of water and nutrients, resulting in the diminution of the plant length and production reduction.

By the other side, Faria et al., [23] noted that the extracts of velvet beans and millet increased the hypocotyl length and the root length of beans, by the other side the Pinus caused reduction of the variables. Pires et al. [24] verified that in the lower concentrations of white lead tree (Leucaena leucocephala) aqueous extract there was stimuli to the aerial part growth in corn plantlets.

According to Maraschin-Silva and Aqüila [25], the application of plant extracts could as well inhibit as stimuli the plantlets growth, due to the presence of allelochemicals, which caused modifications in the membrane functioning, in the absorption of nutrients and water, in photosynthetic and respiration activity, among others.

In relation to the Dry mass of root of bean and corn plantlets parameter, it showed reduction with the elevation of the turnip aqueous extract concentration (Figure 5).
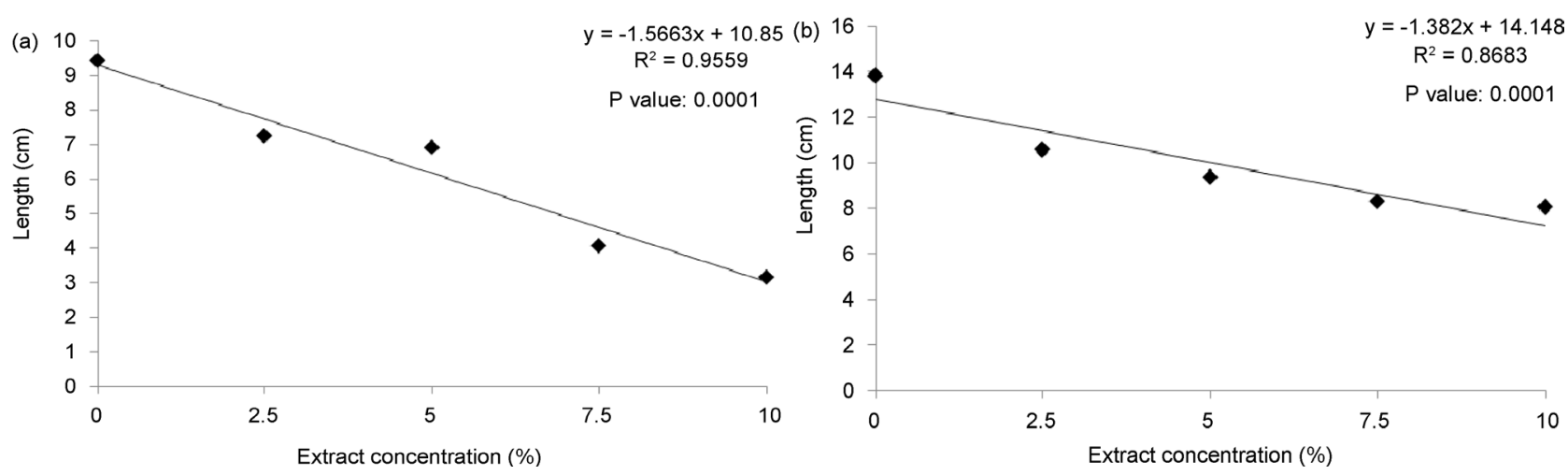

Figure 3. Length of root (cm) of plantlets of (a) - Phaseolus vulgaris L. and (b) - Zea mays L. in different concentrations of turnip's extract. UEL, Londrina, PR, 2015.
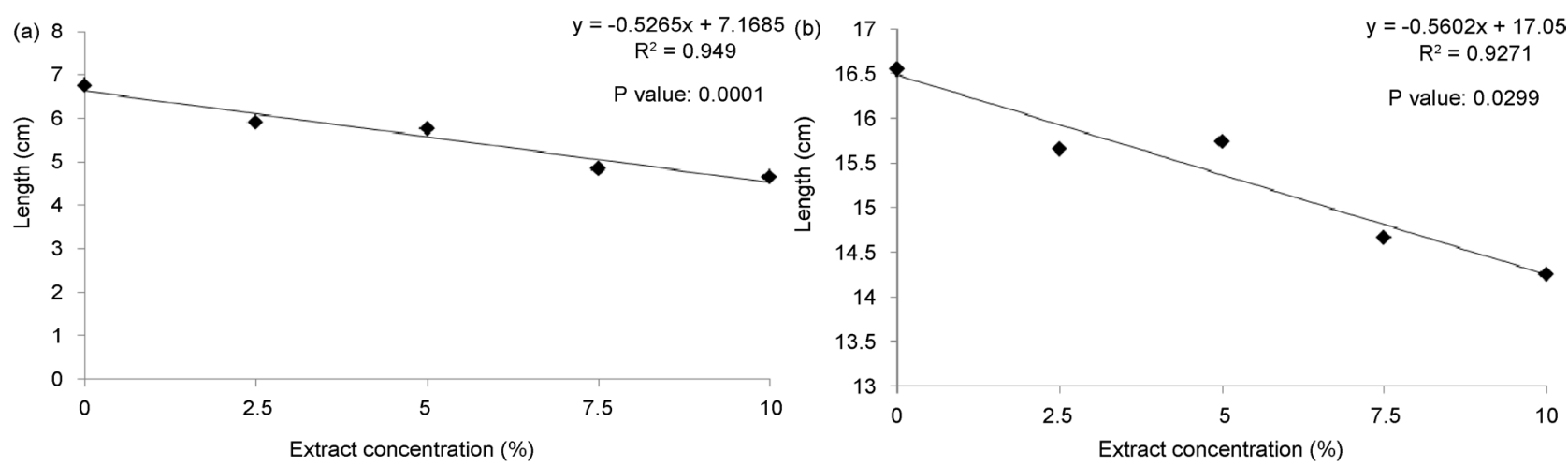

Figure 4. Length of the aerial part (cm) of plantlets of (a) - Phaseolus vulgaris L. and (b) - Zea mays L. in different concentrations of turnip's extract. UEL, Londrina, PR, 2015. 
Moraes et al. [10], working with different haystack levels of cover crops, observed that the increase of the turnip and Egyptian clover (Trifolium vesiculosum) haystack level reduced the dry mass of the root system of blackjack (Bidens sp.).

In accordance with Pires et al. [24], the alterations of the length and dry mass of root are one of the main indicators of the allelopathic effect of plant extracts, being the root normally more sensitive to the allelochemicals effect.

As well as root dry mass, the aerial part's dry mass of bean and corn also presented reduction of values with the elevation of the turnip aqueous extract concentration (Figure 6).

Moraes et al. [10], working with different levels of cover crops haystack, noted that the increase in the turnip, egyptian clover (Trifolium vesiculosum) and australian ryegrass (Lolium multiflorum) haystack levels reduced the dry mass of the aerial parto f blacjack's (Bidens sp.) plantlets.

The plant extract normally does not show significant allelopathic effect in germination of the seeds and show in the development of the root system and aerial part, once these parameters are more sensitive to the presence of naallelochemical in the mean [4]. However the results obtained in this study demontrate that the turnip extract presente influence as well in the seeds germination process as in the development of the root and aerial systems, highlighting in this

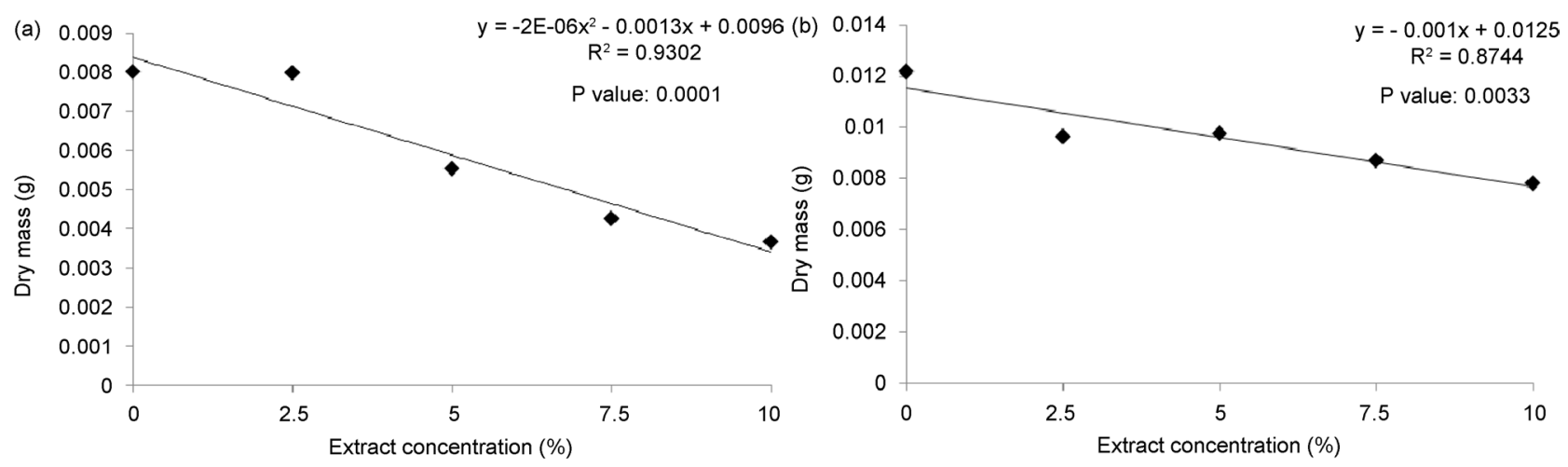

Figure 5. Dry mass of root (g) of plantlets of (a)-Phaseolus vulgaris L.and (b) - Zea mays L. in different concentrations of turnip's extract. UEL, Londrina, PR, 2015.
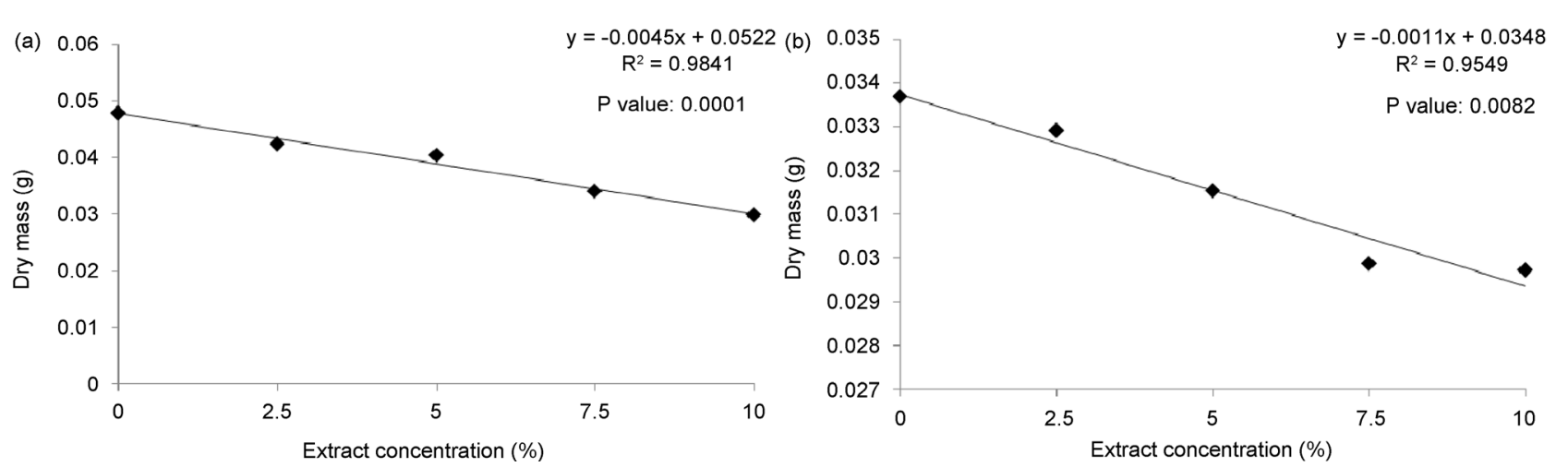

Figure 6. Dry mass of aerial part (g) of plantlets of (a)-Phaseolus vulgaris L. and (b) - Zea mays L. in different concentrations of turnip's extract. UEL, Londrina, PR, 2015. 
way the potential of negative interference on the germination and initial development of the seeds and plantlets of bean and corn. Yet it is known that the allelochemicals present potential of inhibition or stimulation of germination and initial development. Being that those symptoms are allelochemicals actions' secondary reflexes, that by inhibiting, damage or deactivate paths of the metabolic systems of the seed or plantlet, altering the phospholipid bilayer and the system of cellular membranes, the cellular behavior, plant hormonal or photosynthetic [8], resulting in the delay or stimuli of germination or initial growth.

According to Carvalho et al. [26], in the brassiceae Family is possible to find compounds from the glucosinolates group, besides tannins (phenolic acids) and flavonoids, which present a great allelopathic potential. The saponins, the tannins and the flavonoids are among the allelochemicals commonly quoted as responsible by causing direct and indirect effects, may be released in natural conditions, once they are water soluble [4].

In turn, the glucosinolates when decomposed are reduced in Isothiocyanates and thiocyanates [27]. Compounds which in low concentrations, delay the germination, keeping the seeds' viability and in high concentrations could penetrate in big quantities in the seed reacting irreversibly with enzymes, which render the seeds unfeasible [28].

\section{Conclusion}

The aqueous extract of turnip presented the allelopathic effect under the tested seeds and reduced the germination and the plantlets initial development.

\section{References}

[1] Crusciol, C.A.C., Cottica, R.L., Lima, E.V., Andreotti, M., Moro, E. and Marcon, E. (2005) Persistence and Nutrients Release of Forage Turnip Straw Utilized as Mulching in No-Tillage Crop System. Pesquisa Agropecuária Brasileira, 40, 161-168. https://doi.org/10.1590/S0100-204X2005000200009

[2] Amado, T.J.C., Mielniczuk, J. and Vezzani, F.M. (2002) New Recommendation of Nitrogen Fertilization for No-Till Corn in Rs and Sc, Adapted to the Use of Soil Cover Crops. Revista Plantio Direto, 2, 30-34.

[3] Nóbrega, L.H.P., Lima, G.P.D., Martins, G.I. and Menhghetti, A.M. (2009) Soybean (Glycine max L. Merrill) Seed Germination and Plantlet Growth under Vegetation Cover. Acta Scientiarum Agronomy, 31, 461-465.

[4] Ferreira, A.G. and Áquila, M.E.A. (2000) Alellopathy: An Emerging Topic in Ecophysiology. Revista Brasileira de Fisiologia Vegetal, 12, 175-204.

[5] Weir, T.L., Park, S.W. and Vivanco, J.M. (2004) Biochemical and Physiological Mechanisms Mediated by Allelochemicals. Current Opinion in Plant Biology, 7, 472479. https://doi.org/10.1016/j.pbi.2004.05.007

[6] Mendez, A.S.L., Simionato, N.O., Valduga, A.T. and Reginatto, F.H. (2011) Characterization of Extractive Preparations Obtained from Passiflora Alata Curtis. Revista Ciência Farmacológica Básica e Aplicada, 32, 105-111.

[7] Abboud, A.C.S. and Duque, F.F. (1986) Effects of Application of Organic Matters and qe Vermiculite Ln Bean-Maize-Bean Rotation. Pesquisa Agropecuária Brasileira, 21, 227-236. 
[8] Chou, C.H. (2006) Introduction to Allelopathy. In: Reigosa, M.J., Pedrol, N. and Gonzalez, L., Eds., Allelopathy: A Physiological Process with Ecological Implications, Springer, Dordrecht, Holanda, 1-9. https://doi.org/10.1007/1-4020-4280-9_1

[9] Tokura, L.K. and Nóbrega, L.H.P. (2006) Allelopathy of Cover Crop on Weed Plants. Acta Scientiarum, Agronomy, 28, 379-384.

[10] Moraes, P.V.D., Agostinetto, D., Panozzo, L.E., Galon, L., Oliveira, C. and Dal Magro, T. (2012) Allelopathic Potential of Aqueous Extracts of Cover Crops on Thegermination and Development of Bidens pilosa. Semina: Ciências Agrárias, 33, 1299-1314. https://doi.org/10.5433/1679-0359.2012v33n4p1299

[11] Embrapa Solos (2013) Brazilian System of Soil Classification. Centro Nacional de Pesquisa de Solos, Rio de Janeiro.

[12] Brasil. Ministério da Agricultura, Pecuária e Abastecimento (2009) Rules for Seed Analysis. Ministério da Agricultura, Pecuária e Abastecimento, Secretaria de Defesa Agropecuária, Brasília, MAPA/ACS, 395 p.

[13] Maguire, J.D. (1962) Speed of Germination Aid in Selection and Evaluation for Seedling Emergence and Vigor. Crop Science, 2, 176-177. https://doi.org/10.2135/cropsci1962.0011183X000200020033x

[14] Wardle, D.A., Ahmed, M. and Nicholson, K.S. (1991) Allelopathic Influence of Nodding Thistle (Carduus nutans L.) Seed on Germination and Radicle Growth of Pasture Plants. New Zealand Journal Agricultural Research, 34, 185-191. https://doi.org/10.1080/00288233.1991.10423358

[15] Araújo, É.O., Santana, C.N. and Espírito Santo, C.L. (2011) Alellopathic Potential of Vegetable Extracts of Crotalaria Juncea on Germination of Cornand Beans. Revista Brasileira de Agroecologia, 6, 108-116.

[16] Souza Filho, A.P.S. (2002) Potential Allelopathic Activity in Hydroalcoholic and Raw Extracts of Canavalia ensiformis. Planta Daninha, 20, 357-364. https://doi.org/10.1590/S0100-83582002000300005

[17] Rickli, H.C., Fortes, A.M.T., Silva, P.S.S., Pilatti, D.M. and Hutt, D.R. (2011) Allelopathic Effect of Aqueous Extract of Azadirachta Indica A. Juss.on Lettuce, Soybeans, Maize, Beans and Bidens pilosa. Semina: Ciências Agrárias, 32, 473-484. https://doi.org/10.5433/1679-0359.2011v32n2p473

[18] Santos, J.C.F., Souza, I.D., Mendes, A.N.G., Morais, A.D., Conceição, H.D. and Marinho, J.T.S. (2002) Effect of Extracts of Coffee Husks and Rice on Emergence and Growth of Caruru-de-Mancha. Pesquisa Agropecuária Brasileira, 37, 783-790. https://doi.org/10.1590/S0100-204X2002000600007

[19] González, H.R., Mederos, D.M. and Sosa, I.H. (2002) Allelopathic Effects of Remains of Different Species of Medicinal Plants on Basil (Ocimum basilicum L.) under Laboratory Conditions. Revista Cubana de Plantas Medicinales, 7, 67-72.

[20] Politycka, B. and Gmerek, J. (2008) Effect of Ferulic and Pcoumaricacidson the Activity of Hydrolytic Enzymes and Growth of Radicals in Germinating Seeds of Cucumber and Pea. Allelopthy Journal, 21, 227-238.

[21] Ferrarese, M.L.L., Souza, N.E. and Ferrarese Filho, M.L.L. (2000) Ferulic Acid Uptake by Soybean Root in Nutrient Culture. Acta Physiologiae Plantarum, 22, 121 124. https://doi.org/10.1007/s11738-000-0065-7

[22] Sousa, R.O. and Bortolon, L. (2002) Rice (Oryza sativa L.) Roots and Shoots Growth and Nutrients Uptake on Nutrient Solution with Different Acetic Acid Concentrations. Revista Brasileira de Agrociência, 8, 231-235.

[23] Faria, T.M., Gomes Jr., F.G., Sáll, M.E. and Cassiolato, A.M.R. (2009) Allelopathic Effects of Plant Aqueous Extractson Germination, Mycorrhization and Initial 
Growth of Corn, Soybean and Bean. Revista Brasileira de Ciências do Solo, 33, 1625-1633. https://doi.org/10.1590/S0100-06832009000600011

[24] Pires, N.D.M., Souza, I.R.P., Prates, H.T., Faria, T.D., Pereira Filho, I.A. and Magalhães, P.C. (2001) Effect of Leucaena Aqueous Extract on the Development, Mitotic Index and Peroxidase Activity in Maize Seedlings. Revista Brasileira de Fisiologia Vegetal, 13, 55-65. https://doi.org/10.1590/S0103-31312001000100007

[25] Maraschin-Silva, F. and Aquila, M.E.A. (2006) Contribution to the Study of Native Species Allelopathic Potential. Revista Árvore, 30, 547-555.

[26] Carvalho, C.A., Silva, M.B., Oliveira, T.G., Lima, J.M. and Rosa, M.B. (2008) Spectrometric Study at Different Phenologic Stages of the Cabbage (Brassica oleraceae var. capitata). Revista Brasileira de Farmacognosia, 18, 249-257.

https://doi.org/10.1590/S0102-695X2008000200020

[27] Rizzardi, M.A., Neves, R., Lamb, T.D. and Johann, L.B. (2008) Allelopathic Potential of Canola Crop (Brassica napus L. var. oleifera) on Suppression of Hairy Beggarticks (Bidens sp.) and Soybean. Revista Brasileira Agrociência, 14, 239-248.

[28] Petersen, J., Belz, R., Walker, F. and Hurle, K. (2001) Weed Supression by Release of Isothiocyanates from Turnip-Rape Mulch. Agronomy Journal, 93, 37-43.

https://doi.org/10.2134/agronj2001.93137x

Submit or recommend next manuscript to OALib Journal and we will provide best service for you:

- Publication frequency: Monthly

- 9 subject areas of science, technology and medicine

- Fair and rigorous peer-review system

- Fast publication process

- Article promotion in various social networking sites (LinkedIn, Facebook, Twitter, etc.)

- Maximum dissemination of your research work

Submit Your Paper Online: Click Here to Submit

Or Contact service@oalib.com 